\title{
ISLAMIC MUSIC THERAPY THROUGH SHOLAWAT JIBRIL AUDIO TO GROW SELF ACCEPTANCE IN THE ELDERLY
}

\author{
M. Hafid Kumaini' ${ }^{1}$, Nindya Pujiati Yasinta ${ }^{2}$ \\ 1,2Sunan Ampel State Islamic University, Surabaya \\ 1hafidkumaini@gmail.com,2nindyapujiati99@gmail.com
}

\begin{abstract}
Lack of self-acceptance often occurs in someone who is old or elderly who has been abandoned by his wife or husband and left by their children who have built their own household. Islamic Music Therapy through audio Sholawat Jibril is a therapy that aims to calm the heart and always invites to increase spirituality by remembering Allah and Rasulullah SAW. This study uses a qualitative approach, namely the research phase that produces descriptive data in the form of written or spoken words instead of numbers (non-statistical) from the people and observed behavior. Qualitative research obtained from interviews, observations, documentation. Therefore, Islamic music therapy through audio Sholawat Jibril in the program for growing self-acceptance in the elderly is able to grow self-acceptance and positive things that will be very necessary in an effort to increase spiritual feelings in the elderly. With this prayer, it is possible for the elderly to be able to develop a reduced self-acceptance due to the condition that they are old and their relatives who have left the elderly alone.
\end{abstract}

Keywords: Elderly, Islamic Music Therapy, Self Acceptance, Shalawat Jibril

\begin{abstract}
Abstrak Kurangnya Self acceptance sering terjadi pada seseorang yang telah berumur tua atau lansia yang telah ditinggal oleh istri atau suaminya serta ditinggal anakanaknya yang telah membangun rumah tangga sendiri. Terapi Musik Islami melalui audio Sholawat Jibril adalah sebuah terapi yang bertujuan untuk menenangkan hati serta senantiasa mengajak untuk meningkatkan spiritualitas dengan mengingat Allah dan Rasulallah SAW. Penelitian ini menggunakan pendekatan kualitatif, yakni tahapan penelitian yang menghasilkan data deskriptif berupa kata-kata tertulis atau lisan bukan angka (non-statistic) dari orang-orang dan perilaku yang diamati. Penelitian kualitatif diperoleh dari hasil wawancara, obervasi, dokumentasi. Oleh karena itu terapi musik islami melalui audio Sholawat Jibril pada program penumbuhan Self acceptance pada lansia mampu menumbuhkan Self acceptance dan hal-hal positif yang akan sangat diperlukan dalam upaya peningkatan perasaan spiritual pada lansia. Dengan adanya Sholawat tersebut memungkinkan lansia mampu menubuhkan Self acceptance yang berkurang akibat keadaan yang sudah berumur serta sanak keluarganya yang sudah pergi meninggalkan lansia sendirian.
\end{abstract}

Kata Kunci: Lansia, Self Acceptance, Shalawat Jibril, Terapi Musik Islami

\section{A. Introduction}

The process of human life is like a wheel that will continue to spin. Sometimes it's down, sometimes it's above. Early young can work then grow old with a body that gets tired easily. After death, it is continued by the first generation to the next generation and continues like that. Humans will always develop physically and mentally. Childhood is a time when children adjust to their environment, even children will feel that they are part of that environment. ${ }^{1}$ Then the child moves towards adolescence and this transition period is where the child begins to experiment. At

\footnotetext{
${ }^{1}$ Alex Sobur, Psikologi Umum, (Bandung: Pustaka Setia, 2003), pp. 134
} 
the age of 15-18 years, children begin to accept themselves and begin to take responsibility. ${ }^{2}$ Then as adults live in wisdom. Responsibilities began to be borne by adults. Starting from taking care of their children and providing for the needs of the family. Then a person will develop until finally reaching the final development, namely old age or old age.

Old age or old age is a period that will be experienced by people who have a long life. According to the Law on Health Number 13 of 1998 Article 1 paragraph 2 states that the Elderly is someone who has reached the age of 60 years and over. ${ }^{3}$ If a person has reached the age of 60 years and over then according to the law can be categorized as elderly. At this time a person will experience various changes ranging from physical and psychological. According to Havighurst, the physical changes that are often experienced in the elderly are a decrease in strength and endurance so that the elderly need to adjust physically. ${ }^{4}$ With an increasingly old body condition, the elderly will feel mental pressure due to an aging state, the body begins to become weak and is often plagued by disease. Not only that, when a person is old, his children have also grown up, married and left the house. Parents will live with their partners at home and when one of the partners is gone, one of the elderlies will live alone. ${ }^{5}$ So it can be concluded that it triggers psychological changes in the elderly so that complaints arise and are lacking in self-acceptance. Therefore, Self Acceptance needs to be grown.

According to Hurlock, self-acceptance is an individual's ability or desire to live with all the characters that exist in him. Individuals who accept themselves are individuals who do not have problems with themselves. Individuals who accept themselves will have more opportunities to adapt to their environment. ${ }^{6}$ Self-acceptance is always experienced by various groups, especially the elderly who in fact are people who feel that living in the world has been too long. Selfacceptance that usually occurs in the elderly is influenced by the rejection of the elderly when undergoing the process of human development and not accepting the changes in life in the elderly. This causes problems for the elderly, both individual problems and social problems. These problems are individuals who do not accept getting old, do not accept when disease always comes to the body of the elderly, do not accept that their children are not under the same roof with them, leave them, and even their life partner has left their partner alone. ${ }^{7}$

This is similar to what is experienced by the counselee, namely an elderly widow who is 65 years old. Researchers also as therapists take this problem based on the approach and assessment process to the counselee himself and neighbors who are around the counselee's house. The counselee is an elderly man named Mbah Sri (Pseudonym). According to the results of an assessment conducted by researchers, the counselee lives alone at home after a few years ago her husband died of heart disease.

Then the researcher conducted a direct assessment by interview and observation and received information that the counselee has five biological children and has been blessed with eleven grandchildren and one great-grandson. Two of their children are still living in the same sub-district but in different villages and usually they often visit the counselee just to visit and deliver food. The other three children live in different areas which are quite far from Mbah Sri's residence. Actually, his children often visit the counselee. However, due to the COVID-19 pandemic appearing in Indonesia and the implementation of the social distancing system, for one year since 2020 the counselee is rarely visited by his children, even during Ramadan, where all families gather, the counselee does not feel happy. It makes the counselee feel lonely and feel

\footnotetext{
2 Mar'at, S, Psikologi Perkembangan, (Bandung: Rosda, 2006), 140.

3 Undang-Undang Republik Indonesia Nomor 13 Tahun 1998 Tentang Kesejahteraan Lanjut Usia, accessed on Agust, 21, 2021 from https://peraturan.bpk.go.id/Home/Details/45509/uu-no-13-tahun-1998

${ }^{4}$ Alex Sobur, Psikologi Umum, (Bandung: Pustaka Setia, 2003), pp. 139

${ }^{5}$ Sarlito W. Sarwono, Pengantar Psikologi Umum, (Jakarta: Rajawali Pers, 2016), pp. 81

${ }^{6}$ E. B. Hurlock, Psikologi Perkembangan : suatu pendekatan sepanjang rentan

kehidupan, (Jakarta: Erlangga, 1980)

${ }^{7}$ Antry, Arlynda Rizky. "Pengaruh Terapi Dzikir Terhadap Self acceptance (Self Acceptance) Lansia di UPT Pelayanan Sosial Lanjut Usia Blitar di Tulungagung." (Repository IAIN Tulungagung: 2017), pp. 5
} 
unnoticed. Moreover, she has been abandoned by her husband and feels alone. The researcher saw that the counselee's physical condition was healthy, but the counselee often complained about his knee which often hurt when he was invited to walk. The counselee's habit when he is alone is to only watch television and listen to an old radio. His physical condition is not strong enough to walk, so the counselee rarely leaves the house and only relies on wood to support his body when walking.

The thing that can be captured by the researcher from the results of the assessment is that the counselee feels lonely and does not accept himself with the situation. There are several factors that influence the counselee's lack of self-acceptance, namely the COVID-19 pandemic which makes his children rarely come to the counselee's residence, old age conditions make health less and often complain of knee pain when used to walk. After knowing the problems experienced by the counselee, the researcher tries to help the counselee in growing self-acceptance through a relaxation process with Islamic music therapy through Sholawat Jibril accompanied by advice that makes the counselee calmer and fosters good self-acceptance.

Music is something that is not foreign to human ears. Most of the events held in many places must be presented with music. Even today's virtual world is full of music, just like on the TikTok, Youtube, Vidio platforms and others. Music is one of the most useful instruments for humans. With music humans can express themselves. But there are still many people who don't know that music can be used as therapy to entertain themselves and raise the spirit to pray, and grow love. ${ }^{8}$ The use of music therapy is very easy and acceptable to everyone. Enough to be heard in the ear then the sound will be channeled to the auditory nervous system which then processes emotions in the human brain.

Islamic music therapy is a form of therapy using musical instruments that have Islamic, religious, or spiritual nuances. In addition, Islamic music therapy is equipped with Islamic guidance so that clients can further improve their religious side. ${ }^{9}$ An Islamic figure who applied music therapy to a child who was completely paralyzed was Al-Kindi in the 9th Century. Then the use of music as therapy developed during the heyday of the Ottoman Turks and continues to this day. ${ }^{10}$

Shalawat that can be applied as therapy is Shalawat Jibril. Shalawat Jibril is one of the easiest and shortest dhikr shalawat. Named Sholawat Jibril because this Sholawat was first spoken by the Angel Gabriel when he whispered to the Prophet Adam AS as a dowry for Eve.

However, in its application, the researcher uses an audio of Islamic music Shalawat Jibril uploaded on the Santri Njoso Youtube site with the title "Shollallahu'Ala Muhammad Acoustic version of Santri Njoso". The Sholawat sung in the audio meets the criteria as music therapy because it is relaxing and has a tempo of 60 beats per minute. Researchers focused the counselee to listen to the audio with a relaxed body position. By giving Islamic music therapy and a little advice or motivations, it is hoped that it can help the counselee to grow self-acceptance or good self-acceptance. Therefore, researchers are interested in conducting a study entitled "Islamic Music Therapy Through Audio Shalawat Jibril to Grow Self-Acceptance in the Elderly".

\section{B. Theoretical Review}

\section{Music Therapy}

According to the WFMT (World Federation of Music Therapy) or the world federation of music therapy, music therapy is defined as therapy implemented by a therapist using music or musical elements (sound, rhythm, melody, and harmony) to clients with the aim of helping to

\footnotetext{
${ }^{8}$ Don Campbell, Efek Mozart, (Jakarta: Gramedia Pustaka Utama, 2001), pp. 1.

9 Utomo, Ayad Wahyu, and Agus Santoso. "Studi pengembangan terapi musik Islami sebagai relaksasi untuk lansia." Jurnal Bimbingan dan Konseling Islam 3.1 (2014): pp. 63

10 Ibid
} 
achieve a good communication process, as an expression of expression, improve relationships and self-control.11

All types of music can actually be used as therapeutic media, such as relaxation songs, songs that are currently viral, or classical songs. However, the recommended use of songs is songs that have a tempo of about 60 beats per minute or one beat per second. More simply, the tempo of the song is like a ticking clock. It will appear a song that makes the listener relax because of the slow tempo. ${ }^{12}$

In the Islamic world, music has been used by earlier Muslim philosophers as a health therapy. Based on various literatures, figures such as Al-Kindi and Al-Farabi are Muslim scientists who develop music as therapy. In the 9th century, Al-Kindi tried to apply music to a child who was completely paralyzed. Furthermore, the use of music as therapy developed rapidly in the era of the Ottoman Empire's heyday. The development of this music therapy continues to spread throughout the world, including Indonesia. ${ }^{13}$

Music has several types or genres. Each type of music has different characteristics. The use of melodies in several types of music also has a different character. Not only about the melody, music also has different verses in each type. Therefore, everyone always has a preference for different music according to individual characteristics and personalities.

Actually, all types of music can be used as a medium for music therapy. Starting from music in the form of instruments and melodies. The use of certain types of music also affects the mind and body. The selection of music therapy can be tailored to the goals or problems that are being experienced by the client.

In providing music therapy can use two methods, namely:

a. Active music therapy method

That is a method of therapy that is applied through musical activities. It can be said that in this method the client is more invited to be active in mastering music such as playing a musical instrument or learning a musical instrument, singing a piece of music, or making the music itself. However, the use of this method can only be done on clients who do have an interest and can play music actively.

b. Passive music therapy method

This method is often used by therapists to carry out music therapy activities. Because how to use it is very easy and can be applied to many people. How to use it only by listening to and living a music and of course it has been adjusted to the problems experienced. However, this method also has limitations for individuals who have ear defects or are deaf.

\section{Sholawat Jibril}

Mahmud Yunus argues in the Arabic-Indonesian dictionary quoted by Adrika Fithrotul Aini, stating "Shalawat comes from the word 'prayer' whose plural form is Shalawat. So it can be interpreted that Shalawat is a prayer that is said with the aim of remembering Allah continuously. 14

Shalawat has several laws that are flexible according to the circumstances. However, the law of origin of prayer is obligatory. Sholawat is an obligation for everyone who believes in Allah SWT. This is in accordance with the Word of God Almighty. as well as the legal basis for shalawat contained in the Qur'an Surah Al-Ahzab verse 56:

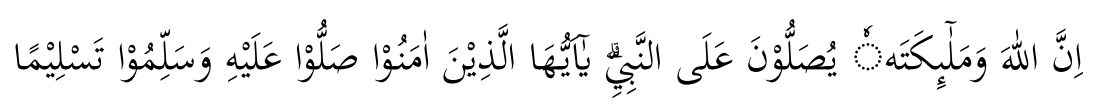

\footnotetext{
11 Djohan, Terapi Musik: Teori Dan Aplikasi, (Yogyakarta: Galang Press, 2006), pp. 28.

12 Rizem Aizid, Sehat Dan Cerdas Dengan Terapi Musik, (Yogyakarta: Laksana, 2011), pp. 103.

13 Ibid, pp. 15

${ }^{14}$ Adrika Fithrotul Aini, "Living Hadis Dalam Tradisi Malam Kamis Majelis Shalawat Addba'bil-Musafa". ArRainiry. Internaional Journal of Islamic Studies 2, No.1, Juni 2014) hlm. 222
} 
"Verily Allah and His angels pray for the Prophet. O you who believe! Pray for the Prophet and greet him with full respect." (Q.S. Al-Ahzab; 56).15

The meaning contained in the verse above is that the law of Sholawat in general is obligatory. Because in the verse it is explained that Allah SWT and His angels always pray to the Prophet Muhammad SAW. Prophet Muhammad SAW was so noble as an enlightened that Allah also recited Shalawat to Prophet Muhammad SAW. And the final meaning of the sentence of the verse is an order from Allah SWT for believers to always pray to the Prophet Muhammad. However, the command is not to acknowledge Prophet Muhammad SAW as God but to acknowledge that Prophet Muhammad SAW was a perfect human being and was chosen by Allah SWT to give mercy to all nature. As the Word of God Almighty stated in Surah Al-Anbiya 'verse 107:

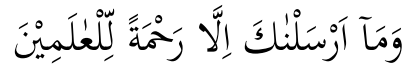

"And We have not sent you (Muhammad) but to (be) a mercy to the whole world." (Q.S. AlAnbiya': 107) ${ }^{16}$

Actually, Sholawat has various forms of poetry. Sholawat Jibril is the only Sholawat that has the shortest verse and the way to practice it is quite easy. The reading of Jibril's prayer is as follows:

\section{Shollallahu 'ala Muhammad}

The short Sholawat poem is the whisper of the Angel Gabriel to the Prophet Adam AS which was used as a dowry to marry his wife, Eve. Therefore, the prayer is called the Sholawat Jibril.

In the book Bada'i al-Zuhur Fi Waqa'i al-Duhur by Sheikh Muhammad bin Ahmad bin Iyas al-Hanafi as quoted by the Salafiyah Sunni Science Library (PISS-KTB) it is stated that Prophet Adam then asked "What is the dowry/dowry? Allah replied, I prevented you from the wheat tree, so do not eat and that is the dowry. Allah SWT then said "صل اله على حبيب محمد" Read Shalawat to my beloved Muhammad. Then Adam asked, who is Muhammad? Allah replied, he will be your posterity and he will be the seal of the prophets. Had it not been for him (Muhammad), I (Allah) would not have created creatures. Then the angel Gabriel approached Adam and whispered to Adam, say Adam:

$$
\text { صَلََّى اللهُ عَلَى عُمَمَّد }
$$

"May the blessings of Allah be upon (Prophet) Muhammad".17

Because Jibril Sholawat is one type of Sholawat, there are several benefits of Sholawat that are obtained by people who always practice Sholawat. There are several benefits when praying according to the Hadith of the Prophet Muhammad SAW, namely: ${ }^{18}$

a. Get double reward

This statement is found in the hadith of the prophet narrated by Imam Muslim, namely:

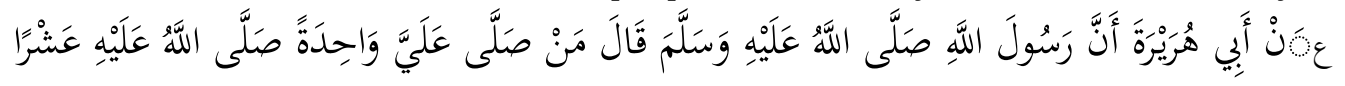

\footnotetext{
${ }^{15} \mathrm{Al}$-Qur'an, Surah Al-Ahzab ayat 56

${ }^{16} \mathrm{Al}$-Qur'an, Surah Al-Anbiya' ayat 107

17 Sholawat Jibril, Apakah Itu? Accessed on $(20$ September 2021) dari http://farmasi.unida.gontor.ac.id/2021/03/30/sholawat-jibril-apakah-itu/

18 Kastolani, 5 Hadis Keutamaan Membaca Shalawat Nabi Muhammad SAW, Artikel daring, https://jatim.inews.id/berita/5-hadis-keutamaan-membaca-shalawat-nabi-muhammad-saw (accessed on 20 September 2021)
} 
Vol. 3 No. 1, 2021

"It was narrated from Abu Hurairah that the Messenger of Allah -peace and prayer of Allah be upon him-said, "Whoever prays to me once, Allah will bless him ten times." (HR. Muslim) [No. 408 Syarh Shahih Muslim] Shahih."

From the explanation of the hadith above, it can be concluded that if we pray then Allah SWT will also pray even up to 10 times to the Prophet Muhammad SAW.

From the explanation of the hadith above, it can be concluded that if we pray, Allah will also pray 10 times to the Prophet Muhammad SAW.

\section{Self-Acceptance}

Self-acceptance (Self-Acceptance) is the ability of each person to be able to accept one's own existence. The results of the self-assessment will be used as the basis for an individual to be able to make a decision in the context of acceptance of one's own existence. Self-acceptance can be done realistically, but it can also be done unrealistically. Realistic acceptance can be characterized by looking at the weaknesses and strengths of oneself objectively. On the other hand, unrealistic self-acceptance is characterized by efforts to overestimate oneself, try to reject one's own weaknesses, deny or avoid bad things from within, such as past traumatic experiences. ${ }^{19}$

Self-acceptance is the extent to which a person can realize and acknowledge personal characteristics and use them in living his life. Self-acceptance is shown by a person's acknowledgment of his strengths as well as accepting his weaknesses without blaming others and having a continuous desire to develop himself.20

In addition, according to him, self-acceptance is a positive attitude that is when individuals accept themselves as human beings. The individual can overcome his emotional state (fear, anger, anxiety, etc.) without disturbing others. Good self-acceptance will only occur if the individual wants and is able to understand his situation as it is, not as he wants it. In addition, have realistic expectations according to his abilities. Thus, if the individual has a pleasant and rational concept of himself, it can be said that the individual likes and accepts him. ${ }^{21}$

Individuals can be said to have good self-acceptance if the individual always believes in himself and always develops himself by establishing relationships with other individuals by not seeing the weaknesses in himself. Individuals who have good self-acceptance also always know their strengths and develop these strengths into a personal character.

From the explanation of some notions of self-acceptance above, it can be concluded that self-acceptance is accepting all the advantages and disadvantages that exist in oneself by always prioritizing the advantages in order to become a good individual character and accepting the shortcomings and turning them into an advantage.

\section{Methods}

Research is a dialogue in which questions are formulated in problem formulation so that solutions can be found in the research process. ${ }^{22}$ This study uses a qualitative approach, which means that a study is conducted to understand the phenomenon of what has been experienced by the research subject holistically by describing it in the form of words or language in a special natural context by utilizing various scientific methods. ${ }^{23}$

\footnotetext{
${ }^{19}$ Ariyo Agoes, Psikologi Perkembangan Anak Usia Tiga Tahun Pertama, (Jakarta: PT Refika Aditama, 2007) pp. 205

${ }^{20}$ Muryantinah Mulyo Handayani, et.al, "Efektivitas Pelatihan Pengenalan Diri Terhadap Peningkatan Selfacceptance dan Harga Diri”, Jurnal Psikologi, 2 (Yogyakarta: Universitas Gajah Mada, 1998)

21 Nurhasyanah. "Faktor-faktor yang Mempengaruhi Self-acceptance Pada Wanita Infertilitas". Jurnal Penelitian dan Pengukuran Psikologi.1, no. 1. (http://journal.unj.ac.id. Accessed in September 2021)

22 Purwanto, Metode Penelitian Kuantitatif Untuk Psikologi dan Pendidikan, (Yogyakarta: Pustaka Belajar, 2008), pp. 9

${ }^{23}$ Lexy J. Meolong, Metode Penelitian Kualitatif, (Bandung: PT Remaja Rosdakarya, 2009),pp. 6
} 
The research was conducted using observation, documentation, and direct experience methods. The purpose of using qualitative research methods is to seek an in-depth understanding of a phenomenon, fact or reality. This can be understood if the researcher explores in depth. Therefore, deep understanding is not possible without observation, documentation, and direct experience. ${ }^{24}$

Then the type of research used is a case study, namely research carried out in detail on research subjects with specific information from the overall background of the problem. ${ }^{25}$ This type of study focuses on empirical phenomenon existing in social community. By using the type, in depth exploration of the data of the research subject can be done thoroughly. Therefore, deep explanation of the phenomenon can be conducted.

\section{Result and Discussion}

Islamic music therapy is characterized by the use of musical instruments or types of music used as therapy, Islamic music and spiritual music. The characteristics of spiritual music are melodic strains that are calming and refer to deep peaceful feelings. ${ }^{26}$ In its application the use of therapy is implemented for the elderly where they will receive auditory stimulation in the form of Islamic music entitled "Shalallahu 'ala Muhammad" which is published on the Santri Njoso Youtube channel. If listened to instantly, the songs published by Santri Njoso have a slow tempo and are in accordance with the criteria for using music therapy, which is no more than 60 beats per minute.

In the process of implementation, the counselee first performs ablution with the aim of cleansing the heart and soul and cooling the body. Then the counselee is invited to lie in bed with a comfortable feeling. After feeling comfortable, the counselee is played with Islamic music taken from the Santri Njoso Youtube page with the title "Shalallahu 'Ala Muhammad". The process of implementing therapy is not done only once, but the counselee is encouraged to always listen to the prayer every morning once a day. It aims to refresh the mind and to always remember Allah and Rasulullah SAW.

After the implementation of therapy for several weeks, the researchers conducted regular observations and conducted interviews with the elderly. The results obtained from the observation are that on the second post-therapy visit, the counselee looks enthusiastic in carrying out household activities such as washing, even the audio music used by therapy is always sounded when carrying out household activities. When walking, even though he was still limping because his legs were still sore, his face was no longer gloomy and the sadness faded.

Then the researcher conducted a brief interview with the elderly. When the researcher asked the situation, the counselee immediately told about Islamic music which was always heard soothing and the heart felt very calm. Then the researcher asked the news about post-therapy and the elderly said that the counselee had surrendered to Allah and said that only Allah could turn things around. The counselee always says that God always gives the best. With the words uttered by the counselee, the researcher can conclude that there is a difference between pre-therapy and post-therapy.

The condition of growing self-acceptance in the elderly can be seen from the counselee who is used to doing activities, who was previously always sad and often even lay in bed because he did not accept the situation. When cleaning in front of the house always scold the neighbors. However, after therapy, the counselee became active and did well at home. Even when the researchers made observations, dishes made by the elderly were also provided. At the time of pretherapy, the psychological condition of the elderly felt that the elderly did not accept living alone and even felt that they were still young and could move freely to and fro. However, at the time of post-therapy, the elderly always accepts their situation and the elderly also have the principle that

\footnotetext{
24 J.R. Raco, Metode Penelitian Kualitatif, (Jakarta: Grasindo, 2010), pp. 1-2

25 Moh. Nazir, Metode Penelitian, (Jakarta: Ghalia Indonesi, 1988), pp. 65

${ }^{26}$ Don Campbell, Efek Mozart, (Jakarta: Gramedia Pustaka Utama, 2001), pp. 98.
} 
everything goes by the will of Allah SWT, so Allah always gives the best whatever it is and it is conveyed to the researchers during the post-therapy visit in 2 weeks.

In this Islamic music therapy, the counselee is given a stimulus in the form of audio Sholawat . But not only Sholawat was heard, when the therapy process was running, the researcher also gave some advice about self-acceptance. As a human being whose rank is not high and can only ask forgiveness from Allah and hope for the intercession of Rasulullah SAW. at the age that has stepped on the elderly, counselees are invited to always remembrance of Sholawat and ask forgiveness from Allah. The counselee is also given advice that Allah SWT also prays to the Prophet Muhammad. So, it is fitting for humans to also pray to the Prophet Muhammad SAW. This encourages the formation of spirituality in the counselee and is directly proportional to the growth of Self-acceptance in the counselee.

\section{E. Conclusion}

Islamic Music Therapy through Audio Sholawat Jibril is able to foster self-acceptance in the elderly. The growth of self-acceptance in the elderly is shown by the behavior or actions of a counselee who is more enthusiastic in living life even without visits from their children and feels comfortable in doing everything, especially household chores. Then the Sholawat of Jibril published by Santri Njoso on the Youtube page with the title "Shalallahu 'Ala Muhammad" can be used as a therapy for dhikr or prayer that calms the heart with a tempo of less than 60 beats per minute.

\section{References}

Agoes, Ariyo. Psikologi Perkembangan Anak Usia Tiga Tahun Pertama. Jakarta: PT Refika Aditama. 2007.

Aini, Adrika Fithrotul. Living Hadis Dalam Tradisi Malam Kamis Majelis Shalawat Addba'bilMusafa. Ar-Rainiry; Internaional Journal of Islamic Studies 2. No.1. (2014).

Aizid, Rizem. Sehat Dan Cerdas Dengan Terapi Musik. Yogyakarta: Laksana. 2011.

Antry, Arlynda Rizky. "Pengaruh Terapi Dzikir Terhadap Self acceptance Self Acceptance Lansia di UPT Pelayanan Sosial Lanjut Usia Blitar di Tulungagung." Repository IAIN Tulungagung. 2017.

Boeree, George. Dasar-dasar Psikologi Sosial. Jogjakarta: Prismasophie. 2006.

Chaplin. J.P. Kamus Lengkap Psikologi. Jakarta: Raja Grafindo Persada. 2005.

Djohan. Terapi Musik: Teori Dan Aplikasi. Yogyakarta: Galang Press. 2006.

Handayani, Muryantinah Mulyo. et.al. "Efektivitas Pelatihan Pengenalan Diri Terhadap Peningkatan Self-acceptance dan Harga Diri". Jurnal Psikologi. 2. Yogyakarta: Universitas Gajah Mada. (1998).

Herlina, Nina. and Annisa Nurjanah. "Membentuk Kecerdasan Otak Janin Selama Kehamilan." Sehat Masada 11.2 2017: 157-161. Accessed on Agust 22, 2021 dari http://ejurnal.stikesdhb.ac.id/index.php/Jsm/article/view/42

Hurlock, E.B. Psikologi Perkembangan: suatu pendekatan sepanjang rentan. Jakarta: Airlangga

Kastolani. 5 Hadis Keutamaan Membaca Shalawat Nabi Muhammad SAW. Artikel daring. https://jatim.inews.id/berita/5-hadis-keutamaan-membaca-shalawat-nabi-muhammadsaw accessed on September 20, 2021

Mar'at. S. Psikologi Perkembangan. Bandung: Rosda. 2006. 
Meilinda, Endah. "Hubungan antara Self acceptance dan Konformitas terhadap Intensi Merokok pada Remaja di SMK Istiqomah Muhammadiyah 4 Samarinda". Jurnal Psikologi. vol. 1. no.1. eJournal Psikologi. 2013. 1 1: 9-22. Accessed in 2021.

Meolong, Lexy J. Metode Penelitian Kualitatif. Bandung: PT Remaja Rosdakarya. 2009.

Nazir, Moh. Metode Penelitian. Jakarta: Ghalia Indonesi. 1988.

Nurhasyanah. Faktor-faktor yang Mempengaruhi Self-acceptance Pada Wanita Infertilitas. Jurnal Penelitian dan Pengukuran Psikologi. Vol.1. no. 1. http://journal.unj.ac.id. Accessed on September 2021.

Purwanto. 2008. Metode Penelitian Kuantitatif Untuk Psikologi dan Pendidikan. Yogyakarta: Pustaka Belajar.

Putri, Arimbi Kaniasih. Hubungan antara Self-acceptance dengan depresi pada wanita perimenopause. Diss. Universitas Airlangga. 2012.

Raco, J.R. Metode Penelitian Kualitatif. Jakarta: Grasindo. 2010.

Sarwono, Sarlito Wirawan. Psikologi Sosial: Individu dan Teori-teori Psikologi Sosial. Jakarta: Balai Pustaka. 2002.

Sholawat Jibril. Apakah Itu?. Accessed on September 20, 2021 dari http://farmasi.unida.gontor.ac.id/2021/03/30/Sholawat -jibril-apakah-itu/

Sobur, Alex. Psikologi Umum. Bandung: Pustaka Setia. 2003.

Sugiarti, Handayani. dan Trisakti. Konsep dan Penelitian Gender. Malang: UMM press. 2008.

Sutrisna, Chomang. Gambaran Asuhan Keperawatan Pemberian Terapi Musik Klasik Untuk Mengatasi Gangguan Pola Tidur Lansia Di Panti Sosialtresna Werdha Denpasar Tahun 2018. Diss. Jurusan Keperawatan. 2018.

Undang-Undang Republik Indonesia Nomor 13 Tahun 1998 Tentang Kesejahteraan Lanjut Usia. accessed on Agust 20,2021 from https://peraturan.bpk.go.id/Home/Details/45509/uuno-13-tahun-1998

Utomo, Ayad Wahyu. and Agus Santoso. "Studi pengembangan terapi musik Islami sebagai relaksasi untuk lansia". Jurnal Bimbingan dan Konseling Islam. 2014: 31

Virlia, Stefani. and Andri Wijaya. "Self acceptance pada penyandang tunadaksa." Seminar Psikologi dan Kemanusiaan Pscyhology Forum UMM. 2015.

Wildana Wargadinata, Spiritual Salawat, (Malang; UIN -MALIKI Press, 2010) 